\title{
PENGARUH PEMBERIAN EKSTRAK BIJI PEPAYA (Carica Papaya L.) DAN EKSTRAK DAUN MIMBA (Azadirachta Indica A. Juss)DAN CAMPURAN EKSTRAK BIJI PEPAYA DAN EKSTRAK DAUN MIMBA TERHADAP KUALITAS SPERMATZOA MENCIT (Mus Musculus)
}

\author{
Waqiatul Hasanah ${ }^{1}$, Sukarjati ${ }^{2}$ \\ 1) Mahasiswa Prodi Biologi FMIPA Universitas PGRI Adi Buana Surabaya \\ ${ }^{2)}$ Staf Pengajar Prodi Biologi, FMIPA Universitas PGRI Adi Buana Surabaya
}

\begin{abstract}
ABSTRAK
Biji papaya (Carica Papaya L.)danDaunMimba(AzadirachtaIndica A. juss )merupakan tanaman herbal.Pada biji papaya mengandung Alkaloid, Papain, Tanin, Saponin, Triterpenoid, Flavonoid, pada bagian daun mimba mengandung Tanin, saponin, Triterpenoid, Flavonoid. Senyawa-senyawa ini merupakan senyawa yang berfungsi sebagai antifertilitas bagi pria. Hal inilah yang mendorong penulis untuk melakukan penelitian mengenai pengaruh ekstrak bijipepaya (Carica Papaya L.) dan ekstrak daun mimba (Azadirachta Indica A. Juss) terhadap kualitas spermatozoa mencit (Mus muscullus). Sampel penelitian ini adalah sperma mencit sebanyak 21 ekor dengan berat badan 20-30 gram, berumur 2,5 bulan. Mencit di bagi 3 kelompok, masing-masing kelompok dibagi 7 perlakuan. Adapun perlakuan yang diberikan adalah kontrol, ekstrak biji papaya, ekstrak daun mimba serta kombinasi kedua ekstrak biji papaya dan daun mimba dengan konsentrasi $0 \mathrm{mg} / \mathrm{kg} \mathrm{bb}, 50 \mathrm{mg} / \mathrm{kg}$ bb dan $100 \mathrm{mg} / \mathrm{kg}$ bb $50: 50 \mathrm{mg} / \mathrm{kg}$ bb, 100:100 mg/kg bb. pemberian ekstrak selama 35 hari. Pada hari ke 37 mencit di bedah untuk diambil cauda epididimis untuk pengamatan kualitas spermatozoa mencit. Penelitian ini merupakan penelitian eksperimental dengan menggunakan Rancangan acak kelompok (RAK). Pengamatan kualitas spermatozoa meliputi motilitas, viabilitas, konsentrasi dan morfologi spermatozoa dengan menggunakan mikroskop. Data yang diperoleh dianalisis dengan analisis varian (ANOVA) Satu arah. Hasil dari penelitian ini menujukkan ada pengaruh ekstrak biji papaya dan ekstrak daun mimba serta kombinasi kedua ekstrak biji papaya dan daun mimba terhadap motilitas $(\mathrm{P}<0,05)$, viabilitas $(\mathrm{P}<0,05)$, morfologi $(\mathrm{P}<0,05)$ dan konsentrasi spermatozoa $(\mathrm{P}<0,05)$. Hasil penelitian ini dapat disimpulkan bahwa ekstrak daun mimba dengan konsentrasi $100 \mathrm{mg} / \mathrm{kg}$ bb adalah perlakuan yang optimal dalam menurunkan viabilitas spermatozoa mencit. Ekstrak kombinasi antara biji papaya dan daun mimba dengan konsentrasi $100 \mathrm{mg} / \mathrm{kg}$ bb adalah perlakuan yang optimal dalam menurunkan motilitas dan konsentrasi spermatozoa mencit.Ekstrak bijipepayadengan konsentrasi $100 \mathrm{mg} / \mathrm{kg}$ bb optimal dalam mengurangi jumlah spermatozoa normal pada mencit.
\end{abstract}

Kata kunci: Ekstrak biji papaya (Carica Papaya L.), Ekstrak Daun Mimba (Azadiracta indica A. Juss), kualitas Spermatozoa Mencit (Mus muscullus)

\begin{abstract}
Seeds of papaya (Carica Papaya L.) and leaves of neem (Azadirachta indica A. Juss) is an herbal plant. In papaya seeds contain of alkaloids, Papain, tannins, saponins, Triterpenoid, Flavonoids. On the part of Neem leaves contain tannins, Saponins, Triterpenoid, Flavonoids. These compounds are compounds that function as antifertility for men. This has led the authors to conduct research on the effect of seed extract of papaya (Carica Papaya L.) and the leaf extract of neem (Azadirachta indica A. Juss) on the quality of spermatozoa of mice (Mus muscullus). The Samples were as many as 21 mice sperm tails with a weight of 20-30 grams, 2-3 months old. Mice divided in the 3 groups, each group was divided 7 treatments. The treatment given is control, papaya
\end{abstract}


seed extract, neem leaf extract and a combination of both papaya seed extract and neem leaves with a concentration of $0 \mathrm{mg} / \mathrm{kg}$ bw, $50 \mathrm{mg} / \mathrm{kg}$ bw and $100 \mathrm{mg} / \mathrm{kg}$ bw $50: 50 \mathrm{mg} / \mathrm{kg} \mathrm{bw}, 100: 100 \mathrm{mg} / \mathrm{kg}$ bw. 35 days for extract. On day 37 mice in surgery for cauda epididymis were taken for observation of the quality of spermatozoa of mice. This study was an experimental study using randomized block design (RAK). The Observation of the quality of spermatozoa includes motility, viability, and morphology of spermatozoa concentration by using a microscope. Data were analyzed by analysis of variance (ANOVA) One Way. The results of this study showed that there is effect of papaya seed extract and neem leaf extract and a combination of both papaya seed extract and neem leaf on motility $(\mathrm{P}<0.05)$, viability $(\mathrm{P}<0.05)$, morphology $(\mathrm{P}<0.05)$ and sperm concentration $(\mathrm{P}<0.05)$. The results of this study concluded that neem leaf extract at a concentration of $100 \mathrm{mg} / \mathrm{kg}$ bw is the optimal treatment in reducing the viability of spermatozoa of mice. Extracts combination of papaya seeds and leaves of neem with a concentration of $100 \mathrm{mg} / \mathrm{kg}$ bw is the optimal treatment in reducing the motility and concentration of spermatozoa of mice. Papaya seed extract at a concentration of $100 \mathrm{mg} / \mathrm{kg}$ bw optimal in reducing the number of normal sperm in mice.

Keywords: papaya seed extract (Carica Papaya L.), Neem Leaf Extract (Azadiracta indica A. Juss), the quality of spermatozoa of mice (Mus muscullus)

\section{PENDAHULUAN}

Indonesia merupakan salah satu negara yang memiliki jumlah penduduk terbesar di dunia. Hal ini karena tingginya laju pertumbuhan penduduk di Indonesia. Laju pertumbuhan penduduk warga Indonesia sebesar $1,49 \%$ setiap tahun. Bila saat ini jumlah penduduk di Indonesia 240 juta jiwa, diperkirakan terjadi penambahan 10.000 bayi lahir setiap hari. Laju pertumbuhan penduduk yang tinggi tersebut akan mempengaruhi tingkat kehidupan dan kesejahteraan penduduk. Hal ini yang memicu pemerintah Indonesia mencanangkan program untuk membatasi pertumbuhan penduduk. Salah satunya dengan KB dan kontrasepsi. Kontrasepsi pria yang umum digunakan saat ini adalah kondom dan vasektomi. Kedua kontrasepsi tersebut memiliki kelemahan antara lain, kontrasepsi kondom memberikan ketidaknyamanan pada pasangan, vasektomi menyebabkan terjadinya gangguan pada imunoglobulin (antibody). Oleh karena itu diperlukan alat kontrasepsi yang memenuhi syarat-syarat antara lain: dapat menimbulkan keadaan azoospermia (semen) total, mudah digunakan, tidak menimbulkan efek samping dan efek toksik, tidak mengganggu libido maupun perilaku seksual serta bersifat reversible. Berdasarkan alasan tersebut maka dikembangkan alternatif kontrasepsi pria dari bahan herbal. Beberapa penelitian menyebutkan bahwa tanaman yang dapat digunakan sebagai kontrasepsi adalah biji pepaya (Carica papaya L.) dan daun mimba (Azadirachia indica A. Juss) Pada penelitian akan ini kedua tanaman tersebut akan dikombinasikan, sehingga dapat mengetahui kualitas spermatozoa pada mencit (mus musculla) jantan.

Menurut Depkes (2006), di Indonesia setidaknya ada 18 tanaman obat yang berpotensi sebagai antifertilitas bagi pria. Beberapa tanaman tersebut antara lain : kembang sepatu (Hibiscus rosa sinensis), pare (Momordica caranti), biji pepaya (Carica papaya L.), kunyit (Curcuma domestica), biji oyong (Luffa acutangula Roxb), daun manggis (Garcinia mangostama), tapak dara (Charantus roseus), biji kapas ( Gossypium hitrusum), cantel ( Andropagon sorgum), sitawar (Costus specious), gandarusa (Justicia gandarusa), mimba (Azadirachta indica Juss), secang (Caesalpinia sappan L.), Leguminosae 
(Erythrina variegata), senggugu (Clerodendrum serratum L.).

Pohon pepaya sudah terkenal sebagai tanaman berkhasiat atau herbal yang dapat menyembuhkan beberapa macam penyakit. Setiap bagian pohon pepaya dapat dimanfaatkan, mulai akar, batang, daun, buah bahkan biji buahnya. Meskipun jenis pepaya sangat banyak, namun yang sekarang dibudidayakan petani hanyalah varietas Bangkok, sedang varietas Cibinong dan Hawaii hanya dibudidayakan secara terbatas. Yang disebut varietas Bangkok adalah pepaya dengan bentuk buntek, bagian tengah agak membesar ujung meruncing, lekukan dan tonjolan yang tajam pada bagian tengah buah (Anonim, 2011). Ukuran pepaya varietas ini sangat besar, diameter buah luasnya mencapai $20 \mathrm{~cm}$, panjangnya $30 \mathrm{~cm}$.

Diantara berbagai jenis tumbuhan liar yang dapat digunakan sebagai obat tradisional yang penting untuk diteliti adalah tanaman pepaya (Carica papaya l). Kandungan kimia yang terdapat pada pepaya adalah mengandung spektrum yang luas dari phytochemical termasuk, polisakarida, vitamin, mineral, enzim, protein, alkaloid, glikosida, lemak dan minyak, lektin, saponin, flavonoid, sterol, dll. Menurut Udoh (1998) biji pepaya (Carica papaya) sebagai antifertilitas sudah diketahui sejak tahun 1970, menyebabkan kuantitas dan kualitas sperma menurun. Potensi antifertilitas ini diperkuat oleh adanya penelitian yang menunjukkan bahwa didalam biji pepaya terkandung senyawa antifertilitas yaitu saponin. Bahan aktif pepaya yaitu triterpenoid saponin yang merupakan salah satu turunan steroid, bahan aktif steroid dan triterpenoid diduga sebagai bahan aktif yang bekerja sebagai faktor antifertilitas. Kedua bahan aktif tersebut diduga mampu mengakibatkan gangguan pada jalur hipotalamus hipofise yang selanjutnya mengakibatkan gangguan sekresi GnRH yang kemudian akan berpengaruh terhadap pembentukan, perkembangan dan pematangan folikel (Borrow et al., 2001).

Alkaloid yang diperoleh dari tanaman
dapat mempengaruhi fisiologi dan metabolisme manusia dan hewan. Dalam sistem reproduksi, alkaloid dapat menekan sekresi hormon reproduksi yaitu testoteron sehingga proses spermatogenesis terganggu dan tanin dapat menyebabkan penggumpalan sperma. Flavonoid mampu menghambat enzim aromatase yaitu enzim yang mengkatalis konversi androgen menjadi estrogen yang meningkatkan hormon testoteron. Testoteron yang tidak stabil akan berakibat feed back negatif pada hipothalamus, sehingga hipothalamus sedikit mensekresikan GnRH (Gonadotropin Releasing Hormone) tidak dapat merangsang hipofisa anterior, sehingga hipofisa anterior sedikit untuk mensekresikan FSH (Follicle Stimulating Hormone) dan LH (Luteinizing Hormone) sehingga proses spermatogenesis terganggu (Susetyarini, 2003).

Biji pepaya (Carica Papaya L.) dan daun mimba (Azadirachia indica Juss) merupakan senyawa tanaman yang berfungsi sebagai pengaruh fertilitas flavonoid, triperpinoid, saponin, dan tannin. Pada biji papaya tidak mengandung senyawa triterpenoid dan saponin, sedangkan daun mimba tidak mengandung senyawa tannin. Untuk itu perlu diteliti tentang kombinasi ekstrak biji papaya (Carica Papaya L.) dan daun mimba (Azadirachia indica Juss). 


\section{MATERI DAN METODE}

Rancangan penelitian yang digunakan adalah Rancangan Acak Lengkap (RAL). Populasi yang digunakan dalam penelitian ini adalah mencit jantan (Mus muscullus) yang berumur $2-3$ bulan dengan berat 20 - 30 gram, yang diperoleh dari PUSVETMA Surabaya. Sampel yang digunakan adalah 21 ekor mencit, terdiri dari 7 perlakuan dengan 3 kali ulangan. Biji pepaya yang digunakan yaitu biji pepaya jenis California yang berwarna coklat sampai hitam. Daun mimba yang digunakan yaitu daun tua yang berwarna hijau tua.

\section{Pembuatan Ekstrak}

Biji pepaya dan daun mimba diletakan dibawah sinar matahari untuk menjadi simplisia, Saat sudah kering, biji pepaya ditumbuk hingga halus, sedangkan untuk daun mimba dihaluskan dengan cara di blender. Setelah semua halus, kemudian membuat ekstrak dengan metode maserasi menggunakan pelarut etanol $70 \%$. Halusan simplisia dibungkus menggunakan kain putih yang tipis kemudian diikat. di masukan kedalam toples dan direndam dengan menggunakan pelarut etanol $70 \%$ selama 3 hari. Setelah 3 hari air ekstrak dipisahkan dari ekstraknya kemudian didestilasi selama 8 jam dengan suhu $70^{\circ} \mathrm{C}$, kemudian hasil destilasi di oven selama $2-3$ hari pada suhu $50^{\circ} \mathrm{C}$.

\section{Persiapan Hewan Coba}

Sebelum mempersiapkan hewan coba terlebih dahulu menyiapkan tempat pemeliharaan hewan coba yang meliputi kandang, tempat makan dan tempat minum mencit dan pakan mencit, kemudian mencit diaklimatisasi pada suhu laboratorium selama 7 hari agar dapat beradaptasi dengan kondisi lingkungan yang baru. Selama proses adaptasi diberi makanan standar, dilakukan pengamatan secara umum serta ditimbang berat badannya sebelum menentukan dosis yang akan diberikan.

\section{Perlakuan}

Jenis ekstrak meliputi ekstrak biji pepaya (A), ekstrak daun mimba (B), Campuran esktrak biji pepaya dan ekstrak daun mimba (C). Dosis ekstrak yang digunakan adalah $0 \mathrm{mg} / \mathrm{kg} \mathrm{BB}, 50$ $\mathrm{mg} / \mathrm{kg} \mathrm{BB}, 100 \mathrm{mg} / \mathrm{kg} \mathrm{BB}, 50: 50 \mathrm{mg} / \mathrm{kg} \mathrm{BB}$, 100:100 mg/kg BB. Ekstrak diberikan secara oral menggunakan sonde dengan volume $1 \mathrm{ml}$. Ekstrak diberikan pada mencit sekali setiap hari selama 35 hari dengan dosis yang telah dihitung sesuai dengan $\mathrm{mg} / \mathrm{kg}$ BB mencit. Pada hari ke-36 seluruh mencit dibius dengan eter atau kloroform, dibedah dan diambil kedua testisnya. Selanjutnya melakukan pemotongan ujung kauda epididimis dan dibagian ampula duktus deferen dipelurut, ditampung di gelas arloji yang berisi 2 tetes larutan $\mathrm{NaCl} 0,9 \%$ kemudian diaduk homogeny untuk dilakukan pengamatan kualitas spermatozoa.

\section{Penghitungan Motilitas spermatozoa mencit}

Penghitungan motilitas spermatozoa dilakukan berdasarkan metode WHO tahun 1999. Spermatozoa mencit segera diambil satu tetes pada obyek glass kemudian ditutup dengan kaca penutup. Penghitungan dilakukan dibawah mikroskop dengan pembesaran 400 kali dengan perhitungan 100 spermatozoa.

\section{Penghitungan Viabilitas spermatozoa mencit}

Larutan spermatozoa diambil satu tetes pada obyek glass. Sampel kemudian ditetesi dengan larutan Eosin-Y satu tetes dicampur, ditutup dengan kaca penutup. Pengamatan dilakukan dibawah mikroskop cahaya dengan pembesaran 400 kali. Presentase jumlah spermatozoa hidup dapat diketahui dengan menghitung jumlah spermatozoa hidup dari 100 spermatozoa untuk setiap ulangan. Spermatozoa yang mati berwarna merah

\section{Penghitungan Morfologi spermatozoa mencit} Morfologi spermatozoa yang normal dan abnormal dilihat pada bagian kepala dan ekor yang berbeda dari normal, misalnya kepala ganda, kepala berukuran kecil atau terlalu besar, tanpa kepala, ekor ganda, ekor tidak lurus, mengkerut, ekor patah, atau tanpa ekor. Pengamatan morfologi 
spermatozoa ditentukan dengan cara membuat sediaan apus dari satu tetes suspensi pada obyect glass spermatozoa dan difiksasi diudara sampai kering, kemudaian di celupkan ke methanol, selanjutnya ditetesi safranin, kemudian dicelup cepat dengan buffer fosfat sebanyak $3 \mathrm{kali}$ selanjutnya diwarnai dengan kristal violet selama 10 menit, dicuci air mengalir dan dikeringkan. Selanjutnya dihitung spermatozoa normal dan abnormal pada 100 spermatozoa untuk setiap ulangan. Penghitungan dilakukan dibawah mikroskop dengan pembesaran 400 kali.

Penghitungan Konsentrasi spermatozoa mencit
Larutan spermatozoa diambil sebanyak $10 \mu 1$ dengan menggunakan pipet mikro. Setelah itu dilakukan pengenceran sebanyak 10 kali dengan

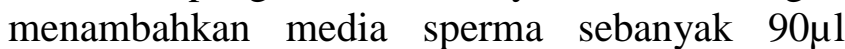
dalam tabung mikro. Sermatozoa tersebut kemudian diteteskan ke dalam kamar hitung hemasitometer Improved Neubauer yang telah diberi kaca penutup.

\section{Analisis Data}

Data ini di uji dengan menggunakan uji one way ANOVA Jika ada pengaruh signifikan $(p<0,05)$ maka analisis data dilanjutkan dengan menggunakan uji LSD (Least Significant Different).

\section{HASIL PENELITIAN}

\section{Motilitas Spermatozoa}

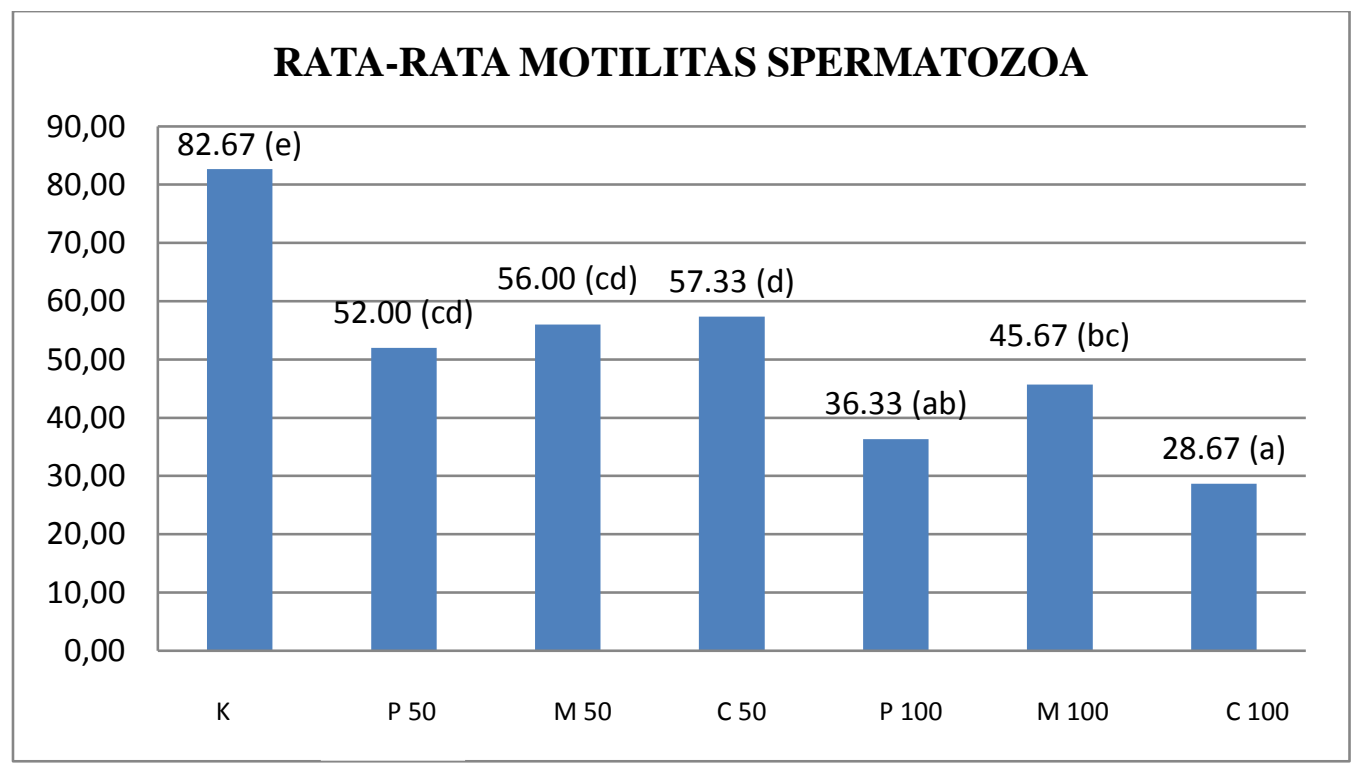

Grafik 1: Pengaruh Pemberian Ekstrak Biji Papaya (Carica Papaya L.) dan Ekstrak Mimba (Azadirachta Indica A. Juss) dan Campuran Ekstrak Biji Papaya dan Ekstrak Daun Mimba terhadap Motilitas (\%) Spermatozoa Mencit ( Mus Muscullus)

$\begin{array}{ll}\mathrm{K} & \text { : Kontrol } \\ \text { P50 } & \text { : Biji Pepaya } 50 \mathrm{mg} / \mathrm{kg} \mathrm{BB} \\ \text { M50 } & \text { : Daun Mimba } 50 \mathrm{mg} / \mathrm{kg} \mathrm{BB} \\ \text { C50 } & \text { : Campuran } 50 \mathrm{mg} / \mathrm{kg} \mathrm{BB} \\ \text { P100 } & \text { : Biji Papaya } 100 \mathrm{mg} / \mathrm{kg} \mathrm{BB}\end{array}$

M100 : Daun Mimba $100 \mathrm{mg} / \mathrm{kg} \mathrm{BB}$

C100 : Campuran $100 \mathrm{mg} / \mathrm{kg} \mathrm{BB}$ 
Berdasarkan grafik 1 pengaruh pemberian ekstrak biji pepaya dan ekstrak daun mimba dan campuran ekstrak biji papaya dan ekstrak daun mimba pada berbagai konsentrasi menyebabkan penurunan motilitas spermatozoa mencit.
Dan yang paling berpengaruh pada motilitas spermatozoa mencit yaitu campuran ekstrak biji papaya dan ekstrak daun mimba dengan dosis ekstrak 100:100 $\mathrm{mg} / \mathrm{kg}$ bb.

\section{VIABILITAS SPERMATOZOA}

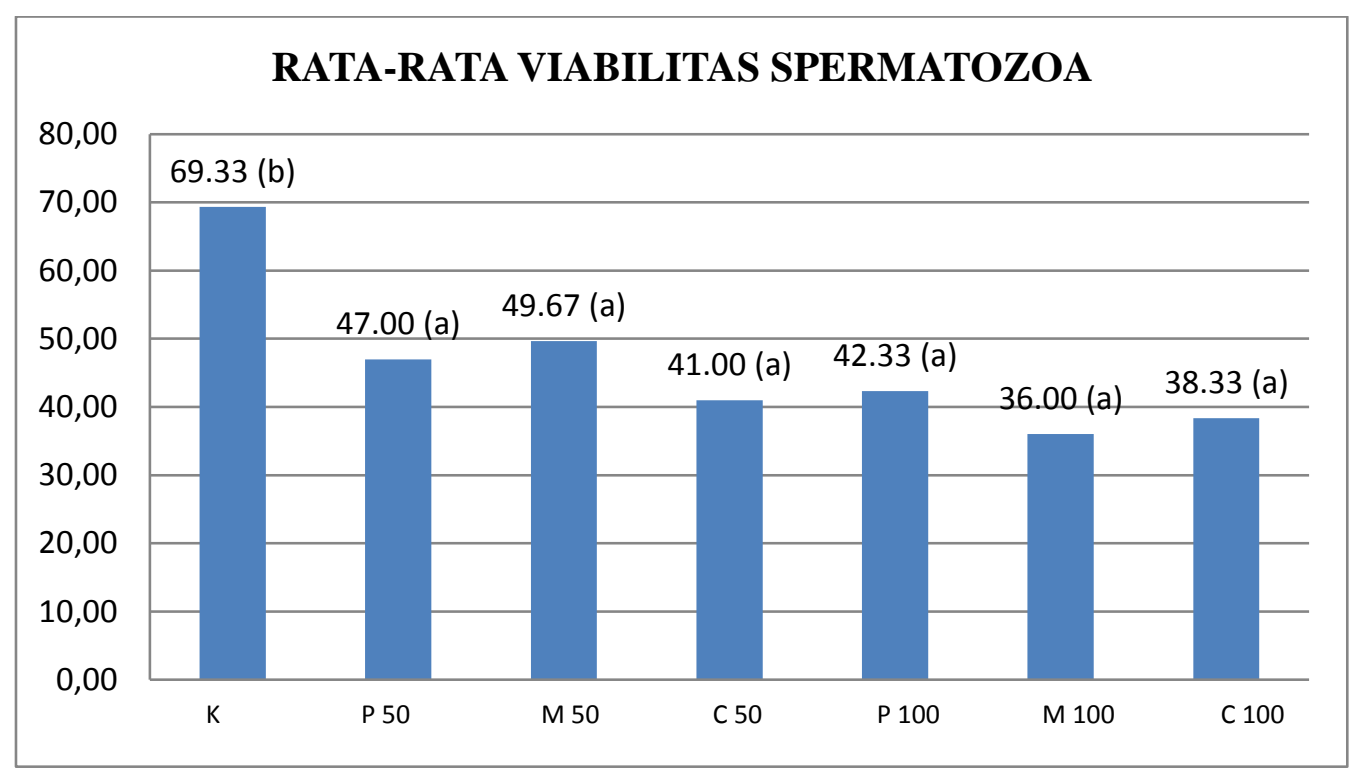

Grafik 2: pengaruh pemberian ekstrak biji papaya (Carica papaya L.) dan daun mimba (Azadirachta indica A. Juss) serta kombinasi antara kedua esktrak biji pepaya dan.ekstrak.daun mimba terhadap viabilitas (\%) spermatozoa pada mencit (Mus muscullus).

Berdasarkan grafik 2 pengaruh pemberian ekstrak biji pepaya dan ekstrak daun mimba dan campuran ekstrak biji papaya dan ekstrak daun mimba pada berbagai konsentrasi menyebabkan penurunan viabilitas spermatozoa mencit. Dan yang paling berpengaruh dalam dalam penurunan viabilitas spermatozoa mencit pada daun mimba dengan dosis ekstrak 100 $\mathrm{mg} / \mathrm{kg} \mathrm{bb}$. 


\section{MORFOLOGI SPERMATOZOA}

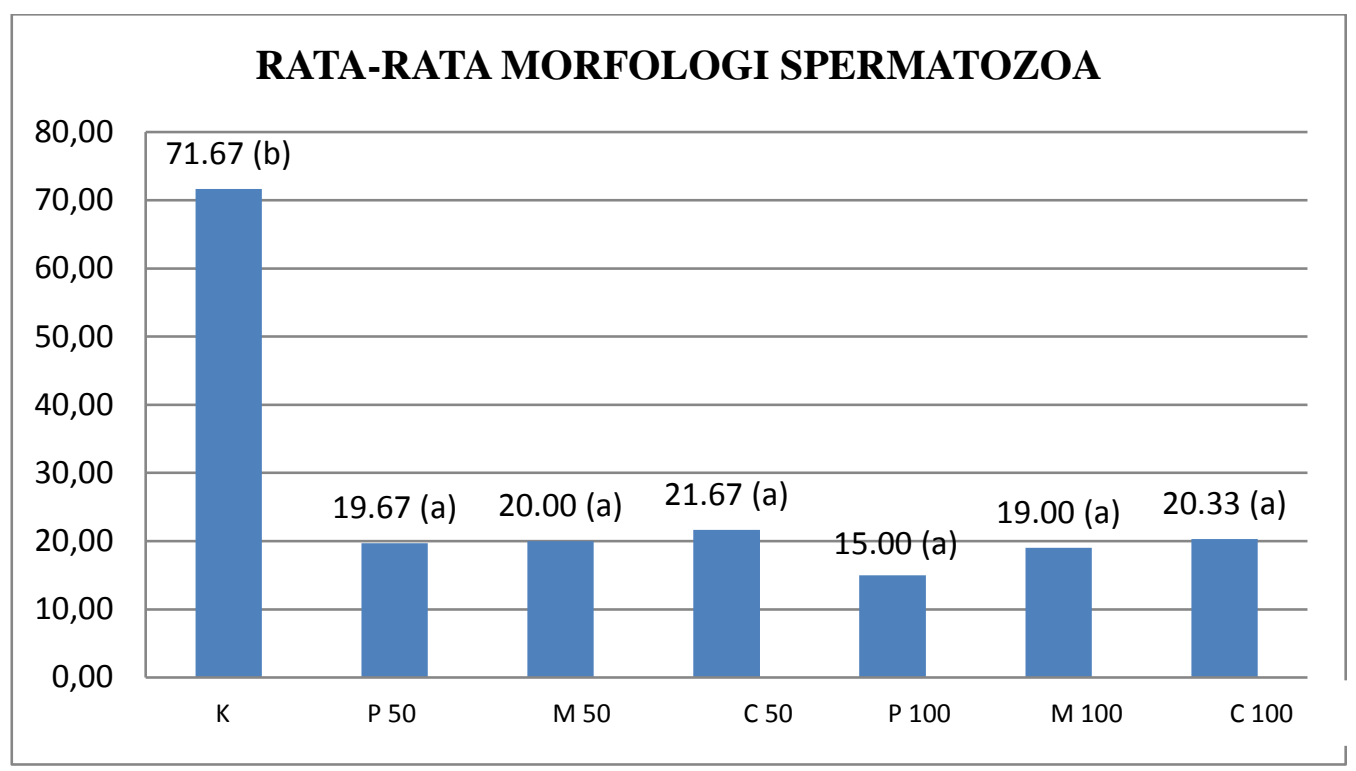

Grafik 3: Pengaruh pemberian ekstrak biji papaya(Carica papaya L.) dan ekstrak daun mimba (Azadirachta indica A. Juss) serta kombinasi antara kedua ekstrak biji papaya dan daun mimba terhadap morfologi normal ( \%) spermatozoa mencit (Mus muscullus).

Berdasarkan grafik 3 pengaruh pemberian ekstrak biji pepaya dan ekstrak daun mimba dan campuran ekstrak biji pepaya dan ekstrak daun mimba pada berbagai konsentrasi menyebabkan penurunan morfologi normal spermatozoa mencit.Dan yang paling berpengaruh pada morfologi normal yaitu biji papaya dengan dosis ekstrak $100 \mathrm{mg} / \mathrm{kg}$ bb. 


\section{KONSENTRASI SPERMATOZOA}

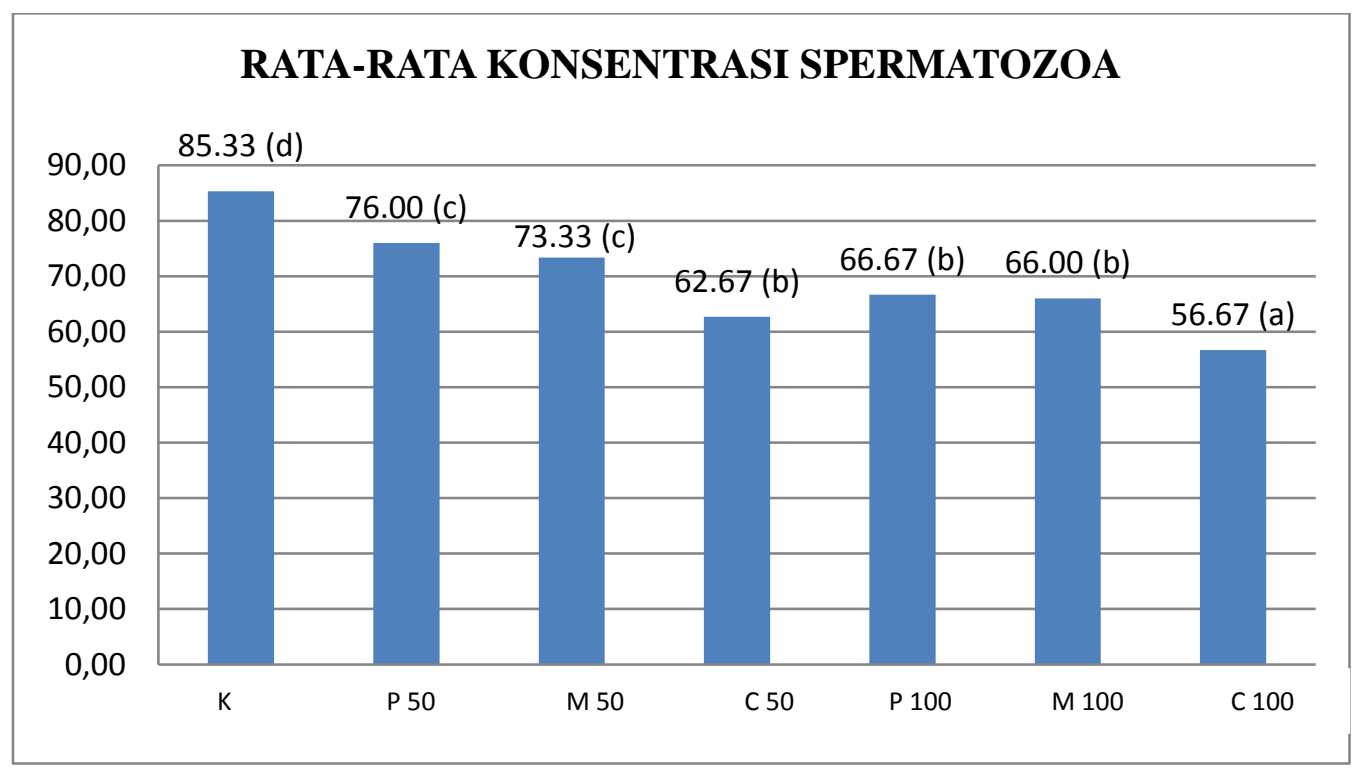

Grafik 4: Pengaruh pemberian ekstrak biji papaya (Carica papaya L.) dan daun mimba (Azadirachta indica A. Juss) serta kombinasi antara kedua ekstrak biji papaya dan daun mimba terhadap konsentrasi ( juta/ml) spermatozoa mencit (Mus muscullus).

Berdasarkan grafik 4 pengaruh pemberian ekstrak biji papaya dan ekstrak daun mimba dan campuran ekstrak biji papaya dan ekstrak daun mimba pada berbagai konsentrasi menyebabkan penurunan konsentrasi spermatozoa

\section{PEMBAHASAN}

Hasil penelitian ini menyatakan bahwa pemberian ekstrak biji papaya (Carica papaya L.) dan ekstrak daun mimba (Azadirachta indica A. juss), baik secara mandiri maupun campuran dapat menurunkan motilitas, viabilitas, morfologi dan konsentrasi spermatozoa mencit. Tanin menurut Herdiningrat (2002), bekerja menganggu proses transport spermaozoa dengan menggumpalkan sperma sehingga pematangan spermatozoa terganggu. Menurut Gufron dkk (2005), hambatan atau gangguan spermatogenesis dapat dilihat
mencit.Dan yang paling berpengaruh pada konsentrasi spermatozoa mencit yaitu campuran ekstrak biji papaya dan ekstrak daun mimba dengan dosis 100:100 mg/kg bb. dari letak sel spermatogenesis yang tidak teratur sehingga lumen tidak mempunyai batas yang tegas. Penelitian Randhawa (2000) menjelaskan bahwa ekstrak daun mimba dapat menurunkan jumlah sel spermatozoa, mengurangi motilitas sperma, menurunkan jumlah sel spermatogonium dan juga menurunkan jumlah sel leydig. Penelitian Nur Fitriani (2015) tentang uji aktifitas ekstrak daun mimba pada tikus putih (Rattus norvegicus) menghasilkan kerusakan beberapa tubulus dan lumen yang kosong pada dosis $25 \mathrm{mg} / \mathrm{BB}$ dan 50 
mg/BB hal ini karena aktifitas salah satu senyawa dalam daun mimba yaitu flavonoid yang bekerja mengkatalisis konfersi androgen menjadi estrogen yang akan meningkatkan hormon testoteron sehingga menyebabkan feed back negatif ke hipofisis yang berdampak pada pelepasan FSH dan LH dan menghambat proses mitosis dan proses spermatogenesis.

Ekstrak yang diberikan pada mencit dapat menimbulkan hambatan proses pada tingkat hipothalamus dan menyebabkan gangguan hormonal sehingga mengakibatkan terjadinya gangguan pada sel leydig dalam mensekresi hormon testosteron. Motilitas spermatozoa dibagi mejadi empat kategori yaitu : spermatozoa bergerak lurus kedepan, spermatozoa bergerak maju lambat, spermatozoa bergerak berputar-putar, dan spermatozoa tidak bergerak. Terdapat dua faktor yang mempengaruhi motilitas sperma yaitu faktor Endogen dan faktor eksogen. Ketersediaan sumber energi merupakan faktor endogen yang sangat penting. Sumber energi yang digunakan dalam motilitas sperma adalah Adenosin Tri Phosphat (ATP). Senyawa aktif yang terkandung dalam biji pepaya seperti alkaloid, tanin, saponin dan tritepenoid. Begitu juga dengan senyawa aktif yang terkandung pada daun mimba seperti taninn, saponin, tritepenoid dan flavonoid dapat menurunkan pada motilitas spermatozoa mencit dikarenakan adanya kandungan dari kedua ekstrak dapat mengganggu proses transportasi sperma, yaitu menggumpalkan sperma sehingga menurunkan motilitas dan daya hidup sperma, akibatnya sperma tidak dapat mencapai sel telur dan pembuahan dapat tercegah menurut (Winarno, 2001). Pada penelitian Nuraini, Tuti (2011) tentang penyuntikan ekstrak biji pepaya pada tikus jantan dengan dosis $40 \mathrm{mg} / \mathrm{bb} 80 \mathrm{mg} / \mathrm{bb}$ $120 \mathrm{mg} / \mathrm{bb}$ didapat hasil bahwa kandungan glikosinolat yang ada pada ekstrak biji pepaya mempengaruhi pembentukan plasma semen. Glukosinolat kemungkinan dapat menghambat pematangan spermatozoa dan mempengaruhi pembentukan plasma semen sebagai media dalam tansport spermatozoa.

Viabilitas spermatozoa adalah daya hidup spermatozoa. Dalam pengamatan viabilitas spermatozoa sperma yang mati berwarna merah. Tujuan pemberian esktrak daun mimba yaitu untuk menurunkan viabilitas spermatozoa mencit dengan kandungan yang ada pada daun mimba seperti flavonoid, saponin, dan alkaloid, senyawa aktif pada daun mimba diduga dapat menyebabkan penghambatan spermatogenesis dan juga menyebabkan kematian sel spermatogenik (Suckow, 2006)

Morfologi spermatozoa pada penelitian ini ditemukan abnormalitas spermatozoa pada pemberian ekstrak biji papaya, namun yang optimal dalam mengurangi spermatozoa normal adalah ekstrak biji papaya degan konsentrasi 100 $\mathrm{mg} / \mathrm{kg}$ bb. Hal ini disebabkan kandungan senyawa papain yang terdapat dalam biji papaya. Papain mempunyai kemampuan menguraikan ikatan-ikatan dalam molekul protein sebagai bahan baku sintesis hormone reproduksi, sehingga protein terurai menjadi polipeptida dan dipeptida akibatnya sintesis hormone reproduksi akan menurun. Papain dapat merusak organel sel sertoli dan sel spermatogenik (spermatogonia spermatosit, spermatid dan spermatozoa). Penurunan jumlah sel sertoli dan sel spermatogenik diakibatkan karena penurunan kadar hormone reproduksi sehingga komponen sel dalam tubulus semineferus mengalami degenerasi.

Spermatozoa ada pada dalam proses maturasi selama berada di dalam saluran epididimis dipengaruhi oleh hormon androgen dan yang disekresikan oleh sel 
epitel epididimis. Didalam tubulus seminiferus androgen berfungsi dan mengontrol proses spermiogenesis pada pembelahan meiosis dan proses spermiogenesis. Gangguan pada maturasi spermatozoa mengakibatkan sperma menjadi abnormal seperti ekor bergulung, kepala tanpa ekor, ekor tanpa kepala, kepala kecil, bagian tengah melipat, ekor melipat, ekor melingkar, putus atau terbelah. Pada penelitian ini diduga senyawa papain yang terdapat didalam biji papaya telah menghambat yang dihasilkannya androgen, sehingga terjadi gangguan pada fase spermiogenesis bila ketersediaannya sedikit atau lebih banyak maka akan menyebabkan proses itu terganggu dan dapat mengakibatkan abnormalitas sperma pada saat spermiogenesis.

Konsentrasi spermatozoa adalah kemampuan bereproduksi dari hewan jantan yang dapat ditentukan oleh kualitas dan kuantitas semen yang dihasilkan. Produksi semen yang tinggi dinyatakan dengan volume semen yang tinggi dan konsentrasi spermatozoa yang tinggi juga. Dalam penelitian ini Penurunan konsentrasi spermatozoa juga disebabkan Kandungan senyawa flavonoid, alkaloid, papain, tanin, triterpenoid dan saponin pada ekstrak campuran yaitu esktrak biji papaya dan ekstrak daun mimba.

KESIMPULAN

Pemberian ekstrak biji pepaya dan ekstrak daun mimba baik secara mandiri maupun campuran dapat menurunkan motilitas, viabilitas, morfologi, dan konsentrasi spermatozoa mencit. Campuran ekstrak biji papaya dan ekstrak daun mimba dengan konsentrasi 100:100 $\mathrm{mg} / \mathrm{kg}$ bb paling berpengaruh terhadap penurunan motilitas dan konsentrasi spermatozoa.

Ekstrak daun mimba dengan konsentrasi $100 \mathrm{mg} / \mathrm{kg}$ bb paling berpengaruh terhadap penurunan viabilitas spermatozoa. Sedangkan yang paling menurunkan morfologi normal spermatozoa adalah ekstrak biji papaya dengan konsentrasi 100 $\mathrm{mg} / \mathrm{kg}$ bb.

\section{DAFTAR PUSTAKA}

Burrow M.E, S.M. Bone, B.M. Coelin, L.I Meinik, B.N Duana, S.W. Canter, T.E.Wiese, T.E Cleveland and J.A. Mc. Lachlan, 2001. Phytochemical Gliceolins Isolated from Soy Medicine Antihormonal Effect Through Estrogen Receptor Alpha and Beta. J. Clin. Endocrinol. Metab. Apr. 86 (4) : 1750-1758

Depkes, 2006. 18 Jenis Tanaman Obat Turunkan Kesuburan Pria. www.depkes.go.id. Diunduh 28

November 2015

Gufron, Herwiyati. 2005. Gambaran Histologik Spermatogenesis Tikus Putih (Rattus norvegicus) diberi Makan Terung Tukak (Solanum forvum). Jurnal Kedokteran Yarsi 2

Herdiningrat, 2002. Gambaran Histologis Testis Mencit (Mus musculus) yang Mendapat Kombinasi Ekstrak Air Biji Pepaya (Carica papaya L.) dan Testoteron Undekanoat (TU). Sumatra Utara : Biologi, Fakultas Matematika dan Ilmu Pengetahuan Alam, Universitas Sumarta Utara

Nuraini, Tuti, 2011. Penyuntikan Ekstrak Biji Carica papaya L. Varietas Cibinong pada Macaca Fascicularis L. dan Kualitas Spermatozoa Serta Kadar Hormon Testoteron. Makalah Kesehatan vol. 16 No.1 : 9-16 
Randhawa NS, B S Parmar. 2000. Neem. New Age International : New Delhi India

Suckow, Weisbroth, Franklin C L,2006. The Laboratory Rat $2^{\text {th }}$ Edition. London : Alsevier Academic Press

Susetyarini, 2003. Pengaruh Dekok Daun Beluntas (Pluchea indica Juss) Terhadap LD 50 (Toksisitas Akut) Tikus Putih Jantan (Ratus norwegicus). Laporan Penelitian Lemlit Universitas Muhammadiyah Malang

Udoh P, Essien I dan Udoh F, 2005. Effect of Carica Papaya (Paw-paw) Seed Extract on the Morphology of Pituitary-Gonadal Axis of Male Wistar Rats. Phytother Res. 19, 1065-1068

Winarno M.W dan D. Sundari, 2001. Informasi Tanaman Obat Untuk Kontrasepsi Tradisional. Cermin Dunia Kedokteran no.120 hal 25-28 